\title{
Rhamdia quelen (Quoy \& Gaimard, 1824), submitted to a stressful condition: effect of dietary addition of the essential oil of Lippia alba on metabolism, osmoregulation and endocrinology
}

\author{
Carine de Freitas Souza ${ }^{1}$, Joseânia Salbego ${ }^{1}$, Luciane T. Gressler ${ }^{1}$, Jaqueline \\ I. Golombieski ${ }^{2}$, Juliana G. Ferst ${ }^{3}$, Mauro A. Cunha ${ }^{1}$, Berta M. Heinzmann ${ }^{4}$, \\ Braulio O. Caron ${ }^{2}$, Werner G. Glanzner ${ }^{3}$, Paulo B. D. Gonçalves ${ }^{3}$ and Bernardo \\ Baldisserotto $^{1}$
}

The aim of this study was to evaluate the effect of the essential oil of Lippia alba (EOLA) as a feed additive on ionoregulatory and metabolic parameters and pituitary hormones expression in silver catfish, Rhamdia quelen, submitted to a stressful condition (stocking density of $10.6 \mathrm{~kg} \mathrm{~m}^{-3}$ and limited space). Fish were fed with different concentrations of EOLA $\left(0.0\right.$ - control, 0.25 and $\left.0.50 \mathrm{~mL} \mathrm{~kg} \mathrm{food}^{-1}\right)$ for 20 days. Metabolic parameters were not affected by the diet, with the exception of alanine aminotransferase, which was higher in the liver of fish fed $0.50 \mathrm{~mL}^{\mathrm{EOLA} \mathrm{kg} \mathrm{food}}{ }^{-1}$. Plasma ions and activity of $\mathrm{H}^{+}$-ATPase did not change, but fish fed $0.25 \mathrm{~mL}$ EOLA kg food ${ }^{-1}$ presented higher $\mathrm{Na}^{+} / \mathrm{K}^{+}$-ATPase activity. Somatolactin expression in the pituitary was higher in the fish fed $0.25 \mathrm{~mL}$ EOLA kg food ${ }^{-1}$, but the expression of growth hormone and prolactin did not change. Therefore, dietary EOLA does not exert a protective effect in $R$. quelen submitted to a stressful situation because it did not alter most measured parameters. The use of $0.25 \mathrm{~mL}^{\mathrm{EOLA} \mathrm{kg} \text { food }}{ }^{-1}$ seems to be more suitable than $0.50 \mathrm{~mL}^{\mathrm{EOLA} \mathrm{kg} \text { food }}{ }^{-1}$ since the latter may be related to liver damage.

O objetivo deste estudo foi avaliar o efeito do óleo essencial de Lippia alba (OELA) como aditivo em rações na ionoregulação, parâmetros metabólicos e expressão de hormônios hipofisários em jundiás, Rhamdia quelen, submetidos a uma situação estressante (densidade de estocagem de $10,6 \mathrm{~kg} \mathrm{~m}^{-3}$ e espaço limitado). Os peixes foram alimentados com

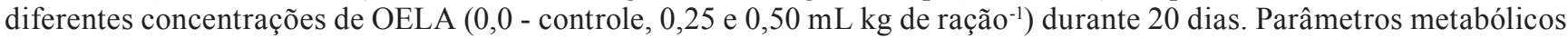
não foram afetados pela dieta, com a exceção da alanina aminotransferase, que foi mais elevada no fígado dos peixes alimentados com $0,50 \mathrm{~mL}$ de OELA $\mathrm{kg}$ de ração ${ }^{-1}$. Íons plasmáticos e a atividade da $\mathrm{H}^{+}$-ATPase não apresentaram nenhuma alteração, mas os peixes alimentados com $0,25 \mathrm{~mL}$ OELA kg de ração-1 apresentaram maior atividade da $\mathrm{Na}^{+} /$ $\mathrm{K}^{+}$-ATPase. A expressão da somatolactina na hipófise de peixes alimentados com $0,25 \mathrm{~mL}$ OELA kg de ração $\mathrm{o}^{-1}$ aumentou, porém a expressão do hormônio de crescimento e da prolactina não mudou. Portanto, a adição do OELA na ração não tem um efeito protetor em jundiás submetidos a uma situação estressante, pois não influiu na maioria dos parâmetros medidos. O uso de $0,25 \mathrm{~mL}$ OELA kg de ração-1 parece ser mais adequado que $0,50 \mathrm{~mL}$ OELA kg de ração ${ }^{-1}$, uma vez que este nível de inclusão pode estar relacionado a danos hepáticos.

Keywords: Cortisol, Enzymatic activity, Growth hormone, Somatolactin.

${ }^{1}$ Departamento de Fisiologia e Farmacologia, Universidade Federal de Santa Maria (UFSM), Av. Roraima s/n, 97105-900 Santa Maria, Rio Grande do Sul, RS, Brazil. (CFS) carinedefs@yahoo.com.br, (JS) josalbego2004@yahoo.com.br, (LTG) lutgressler@hotmail.com, (MAC) cunha.mauroalves@gmail.com,(BB) bbaldisserotto@hotmail.com (corresponding author)

${ }^{2}$ Departamento de Agronomia e Ciências Ambientais, UFSM, Centro de Educação Superior Norte do RS, 98400-000 Frederico Westphalen, RS, Brazil. (JIG) jgolombieski@yahoo.com.br, (BOC) otomarcaron@yahoo.com.br.

${ }^{3}$ Departamento de Clínica de Grandes Animais, UFSM, Santa Maria, RS, Brazil. (WGG) wernergiehl@gmail.com, (JGF) juferst@ hotmail.com, (WGG) wernergiehl@gmail.com, (PBDG) bayard@biorep.ufsm.br

${ }^{4}$ Departamento de Farmácia Industrial, UFSM, Santa Maria, RS, Brazil. berta.heinzmann@gmail.com 


\section{Introduction}

Addition of herbal extracts in fish feed is increasingly seen as a safe and practical alternative to synthetic pharmaceuticals. Some studies showed that dietary addition of plants has several advantages. The addition of $0.5 \%$ of Massa medicata, Crataegi fructus, Artemisia capillaries or Cnidium officinale to the diet led to better use of lipids in stress and recovery of Pagrus major (Ji et al., 2009). The use of the oregano essential oil (Origanum heracleoticum) as a supplement in the food improved growth, antioxidant status and resistance against Aeromonas hydrophila in channel catfish (Ictalurus punctatus) (Zheng et al., 2009) and the extract of Allium sativum in the diet also promoted growth and reduced mortality rate of Nile tilapia (Oreochromis niloticus) challenged with Aeromonas hydrophila (Shalaby et al., 2006).

The plant Lippia alba (Verbenaceae) is found in South and Central America and tropical areas of Africa (Terblanche \& Kornelius 1996). In Rhamdia quelen (Quoy \& Gaimard 1824), the essential oil of L. alba (EOLA) is an effective anesthetic (Cunha et al., 2010) and sedative for transport (Azambuja et al., 2011; Becker et al., 2012), can delay lipid peroxidation (LPO) during frozen storage of fillets (Veeck et al., 2013) and decreases LPO and increases tissue antioxidant response when added to the diet (Saccol et al., 2013). The EOLA is also an effective anesthetic for the sea horse (Hippocampus reidi) (Cunha et al., 2011).

The pituitary hormones control several physiological processes. Growth hormone (GH) is related to growth, metabolism, stress (Laiz-Carrión et al., 2009; Sinha et al., 2012), and osmoregulation (Sakamoto \& McCormick 2006). Prolactin (PRL) also participates in the control of growth, stress and osmoregulation (Sakamoto \& McCormick 2006; Laiz-Carrión et al., 2009), while somatolactin (SL) is apparently related to energy balance, acid-base equilibrium (Kakizawa et al., 1996; Furukawa et al., 2010), stress (Laiz-Carrión et al., 2009) and metabolism (Company et al., 2001). Cortisol, produced by the interrenal cells, is the main glucocorticoid and mineralocorticoid steroid in fish, and is a good indicator for assessing primary stress (Mommsen et al., 1999).

Rhamdia quelen can be found from Argentina to southern Mexico (Perdices et al., 2002), and is the most raised native species in South Brazil (Baldisserotto, 2009). A recent study demonstrated that feeding $R$. quelen with different levels of dietary EOLA for 60 days does not affect growth, but alters some metabolic parameters and improves the antioxidant status (Saccol et al., 2013). However, it is not known whether the effect of EOLA on anesthesia and antioxidant status may induce any protective effect in $R$. quelen exposed to non-optimal culture situations, as at a stocking density of $10.6 \mathrm{~kg} \mathrm{~m}^{-3}$, which is considered stressful for this species when fish are maintained in a limited space (tanks or cages around up to 300-400 L) (Barcellos et al., 2004; Menezes et al., 2015). Consequently, the aim of this study was to evaluate metabolic, osmoregulatory and endocrinological parameters of $R$. quelen fed with a diet containing different levels of EOLA and submitted to a stressful situation.

\section{Material and Methods}

Essential oil. The plant $L$. alba was cultivated in the Centro de Educação Superior do Norte (CESNORS-UFSM) Frederico Westphalen Campus. A voucher specimen (SMDB 10050) was deposited in the herbarium of the Department of Biology (UFSM). Botanical identification was made by Gilberto Dolejal Zanetti (Department of Industrial Pharmacy, UFSM). The EOLA was obtained from fresh leaves of $L$. alba by hydrodistillation in a Clevenger apparatus for $2 \mathrm{~h}$ (Council of Europe (COE), 2007) and stored at $-20^{\circ} \mathrm{C}$ until use. The composition of the EOLA was the same as that described by Saccol et al. (2013): the major components of the EO were linalool (55.26\%), 1,8-cineole (7.85\%), $\gamma$-muurolene (4.63\%), $\beta$-caryophyllene (3.15\%) and $E$-carveol (2.79\%).

Experimental design. The experiment was conducted through January and February 2013 (summer), natural photoperiod (15 h light, $9 \mathrm{~h}$ darkness) in a continuously aerated recirculation system at the Laboratory of Fish Physiology, Universidade Federal de Santa Maria (UFSM). Adult $R$. quelen $(132.74 \pm 10.24 \mathrm{~g}, 24.05 \pm 0.55 \mathrm{~cm}$, voucher number UFRGS 19612, Ichthyology Laboratory, Universidade Federal do Rio Grande do Sul) of both sexes were obtained from the Fish Culture sector (UFSM) and placed in $60-\mathrm{L}$ tanks (4 fish/tank) at a stocking density of $10.6 \mathrm{~kg} \mathrm{~m}^{-3}$.

The animals were fed to satiation once a day (15:00) with a diet (34\% crude protein) formulated according to Lazzari et al. (2007) (Table 1). Three concentrations of the EOLA in the diet (0-control, 0.25 and $\left.0.50 \mathrm{~mL} \mathrm{~kg} \mathrm{food}^{-1}\right)$ were added to the ingredients together with canola oil. The EOLA concentrations were the lowest concentrations that improved antioxidant status in $R$. quelen (Saccol et al., 2013). The amount of feed offered and the unconsumed remains were weighed to determine feed intake. The fish $(\mathrm{n}=10 /$ dietary EOLA concentration) were fed with the control diet for one week prior to the experiment for acclimation to the system and to the diet, and then for additional 20 days with the treatment diets. Uneaten food and feces were siphoned 30 minutes after feeding, and the water removed in this process was replaced with water under the same conditions and proportions found in the system.

The experimental protocol was approved by the Committee on Animal Experimentation - UFSM, under the registration number 46/2010. 
Table 1. Formulation of the experimental diets. ${ }^{a}$ Vitamin and mineral mixture (security levels per kilogram of product)folic acid: $250 \mathrm{mg}$, pantothenic acid: $5000 \mathrm{mg}$, antioxidant: 060 g, biotin: $125 \mathrm{mg}$, cobalt: $25 \mathrm{mg}$, copper: $2000 \mathrm{mg}$, iron: $820 \mathrm{mg}$, iodo: $100 \mathrm{mg}$, manganese: $3750 \mathrm{mg}$, niacin: $5000 \mathrm{mg}$, selenium: $75 \mathrm{mg}$, vitamin A: $1000000 \mathrm{UI}$, vitamin B1: 1250 $\mathrm{mg}$, vitamin B12: $3750 \mathrm{mcg}$, vitamin B2: $2500 \mathrm{mg}$, vitamin B6: $2485 \mathrm{mg}$, vitamin C: $28000 \mathrm{mg}$, vitamin D3: $500000 \mathrm{UI}$, vitamin E: 20000 UI, vitamin K: $500 \mathrm{mg}$, zinc: $17500 \mathrm{mg}$.

\begin{tabular}{|c|c|c|c|}
\hline \multicolumn{2}{|l|}{ Ingredients } & \multicolumn{2}{|l|}{$(\%)$} \\
\hline \multicolumn{2}{|l|}{ Soybean meal } & \multicolumn{2}{|l|}{30} \\
\hline \multicolumn{2}{|l|}{ Meat and bone meal } & \multicolumn{2}{|l|}{35} \\
\hline \multicolumn{2}{|l|}{ Rice bran } & \multicolumn{2}{|l|}{12} \\
\hline \multicolumn{2}{|l|}{ Corn } & \multicolumn{2}{|l|}{15} \\
\hline \multicolumn{2}{|l|}{ Canola oil } & \multicolumn{2}{|l|}{3} \\
\hline \multicolumn{2}{|l|}{ Salt } & \multicolumn{2}{|l|}{1} \\
\hline \multicolumn{2}{|c|}{ Vitamins and minerals (premix) ${ }^{a}$} & \multicolumn{2}{|l|}{3} \\
\hline \multicolumn{2}{|l|}{ Phosphate dicalcium } & \multicolumn{2}{|l|}{1} \\
\hline Analysis of the feed (\%) & $0.00 \mathrm{~mL} \mathrm{~kg}^{-1}$ & $0.25 \mathrm{~mL} \mathrm{~kg}^{-1}$ & $0.50 \mathrm{~mL} \mathrm{~kg}^{-1}$ \\
\hline Dry matter & 95.43 & 95.48 & 95.56 \\
\hline Ashes & 14.97 & 15.15 & 15.58 \\
\hline Crude protein & 38.96 & 38.98 & 39.07 \\
\hline Fat & 10.42 & 9.92 & 10.08 \\
\hline
\end{tabular}

Water sampling and analyses. The water parameters measured daily during the experimental period and their respective values were: dissolved oxygen $6.85 \pm 0.12 \mathrm{mg} \mathrm{L}^{-1}$ and temperature $24.0^{\circ} \mathrm{C} \pm 0.2$ (oxygen meter Y5512; YSI Inc., Yellow Springs, OH, USA); pH $7.15 \pm 0.06$ (DMPH-2 pH meter, Digimed, São Paulo, SP, Brazil); total ammonia nitrogen levels $0.85 \pm 0.11 \mathrm{mg} \mathrm{L}^{-1}$ (American Public Helth Association (APHA), 2005) and un-ionized ammonia $\left(\mathrm{NH}_{3}\right)$ levels $0.007 \pm$ $0.001 \mathrm{mg} \mathrm{L}^{-1}$ (Colt, 2002). Alkalinity $29.5 \pm 1.0 \mathrm{mg} \mathrm{L}^{-1} \mathrm{CaCO}_{3}$ (Boyd \& Tucker, 1992) and water hardness $26.0 \pm 1.4 \mathrm{mg} \mathrm{L}^{-1}$ $\mathrm{CaCO}_{3}$ (EDTA titrimetric method) were determined weekly.

Sample collection. After being fasted for $24 \mathrm{~h}$, fish were anesthetized with $50 \mathrm{mg} \mathrm{L}^{-1}$ eugenol and blood was collected by caudal puncture with heparinized $5 \mathrm{~mL}$ syringes. The samples were centrifuged at $1000 \mathrm{xg}$ for $5 \mathrm{~min}$ and the plasma was stored at $-20^{\circ} \mathrm{C}$ until analyses. The fish were then euthanized and the pituitary gland, gills, liver and muscle were excised and stored in a $-80^{\circ} \mathrm{C}$ freezer.

RNA Extraction and cDNA synthesis. Total RNA was extracted from pituitary using Trizol reagent (Invitrogen) according to manufacture instructions. Total RNA quantity and purity were assessed by NanoDrop (Thermo Scientific, Delaware, USA; Abs 260/280 nm ratio) spectrophotometer. Ratios above 1.7 were considered pure and samples below this threshold were discarded. Total RNA $(1 \mu \mathrm{g})$ was treated with DNase (Invitrogen) at $37{ }^{\circ} \mathrm{C}$ for 5 min to digest any contaminating DNA. The reverse transcriptase reaction was performed with iScript cDNA synthesis kit (Bio-Rad) in a final volume of $20 \mu \mathrm{L}$.
Pituitary expression of GH, PRL and SL mRNA. The mRNA expression was analyzed through qRT-PCR, using the StepOnePlus ${ }^{\text {TM }}$ RT-PCR system (Applied Biosystems) with Power SYBR Green PCR Master Mix (Applied Biosystems). The sequences used to design all the primers were according to Baldisserotto et al. (2014) using the Primer Express software 3.3 (Applied Biosystems). The results were normalized to the expression of the constitutive gene $\beta$-actin according to Baldisserotto et al. (2014). The calculation of relative expression was performed as recommended by Pfaffl (2001).

Cortisol. Plasma cortisol was determined in duplicates using an enzyme-linked immunosorbent assay (ELISA) kit (Diagnostics Biochem Canada Inc., Canada). Absorbance was determined in spectrophotometer at $450 \mathrm{~nm}$, and the inter- and intra-assay variation coefficients were $5.15 \pm 0.53 \%$ and $4.13 \pm 0.67 \%$ respectively. The specificity of the test was evaluated by comparing the standard curve and serial dilutions of the plasma samples. The curve obtained using serial dilutions of $R$. quelen plasma ran parallel to the curve constructed with human standards provided by the kit.

Biochemical measurements. The protein content in liver and muscle was measured according to Lowry et al. (1951) using bovine serum albumin as standard. Plasma glucose and lactate were measured with Labtest kits (Lagoa Santa, MG, Brazil). Glycogen and glucose in the liver and muscle were determined according to Dubois (1956). Lactate in the muscle was determined as in Harrower \& Brown (1972) and total lipids were determined in the liver and muscle by the method of Bligh \& Dyer (1959). Activities of aspartate aminotransferase (AST) and alanine aminotransferase (ALT) in plasma and liver were determined colorimetrically according to Reitman \& Frankel (1957).

Ionoregulatory measurements. Plasma $\mathrm{Cl}^{-}$levels were determined according to Zall et al. (1956) and $\mathrm{Na}^{+}$and $\mathrm{K}^{+}$ with a flame spectrophotometer B262 (Micronal, São Paulo, Brazil). Standard solutions were made with analytical reagent grade (Vetec Merck) dissolved in deionized water, and standard curves for each ion were tested at five different concentrations. The activities of $\mathrm{Na}^{+} / \mathrm{K}^{+}$-ATPase and $\mathrm{H}^{+}$ATPase were assessed in the gills as described by Gibbs \& Somero (1989).

Statistical Analyses. A Levene test was conducted to evaluate the homogeneity of variances. The data were compared using one-way analysis of variance (ANOVA) followed by the Tukey's test. The data regarding GH were not homocedastic and were compared using the KruskalWallis test followed by the multiple comparison of mean ranks for all groups. All analyzes were performed with the software Statistica 7.0 (Stat Soft, Tulsa, OK). The minimum level of significance was $\mathrm{P}<0.05$. The results were expressed as the mean \pm standard error of the mean (SEM). 


\section{Results}

Feed consumed and metabolic parameters. The amount of feed consumed per day was similar in the different treatments ( $\mathrm{g}$ feed kg fish $\left.{ }^{-1}\right): 1.70 \pm 0.1 \mathrm{~g} \mathrm{~kg}^{-1}$ for control, 1.32 $\pm 0.1 \mathrm{~g} \mathrm{~kg}^{-1}$ for those fed $0.25 \mathrm{~mL}^{-1 O L A ~ k g}$ food $^{-1}$ and 1.36 $\pm 0.2 \mathrm{~g} \mathrm{~kg}^{-1}$ for those fed $0.50 \mathrm{~mL}$ EOLA kg food ${ }^{-1}$. Glycogen (liver and muscle), glucose (plasma, liver and muscle), lactate (plasma and muscle), protein, total lipids, plasma cortisol (Fig. 1 and Table 2) and AST (plasma and liver) (Fig. 2A) were not affected by the dietary EOLA. Hepatic ALT of fish fed $0.50 \mathrm{~mL}$ EOLA kg food ${ }^{-1}$ was significantly higher compared to the other treatments (Fig. 2B).
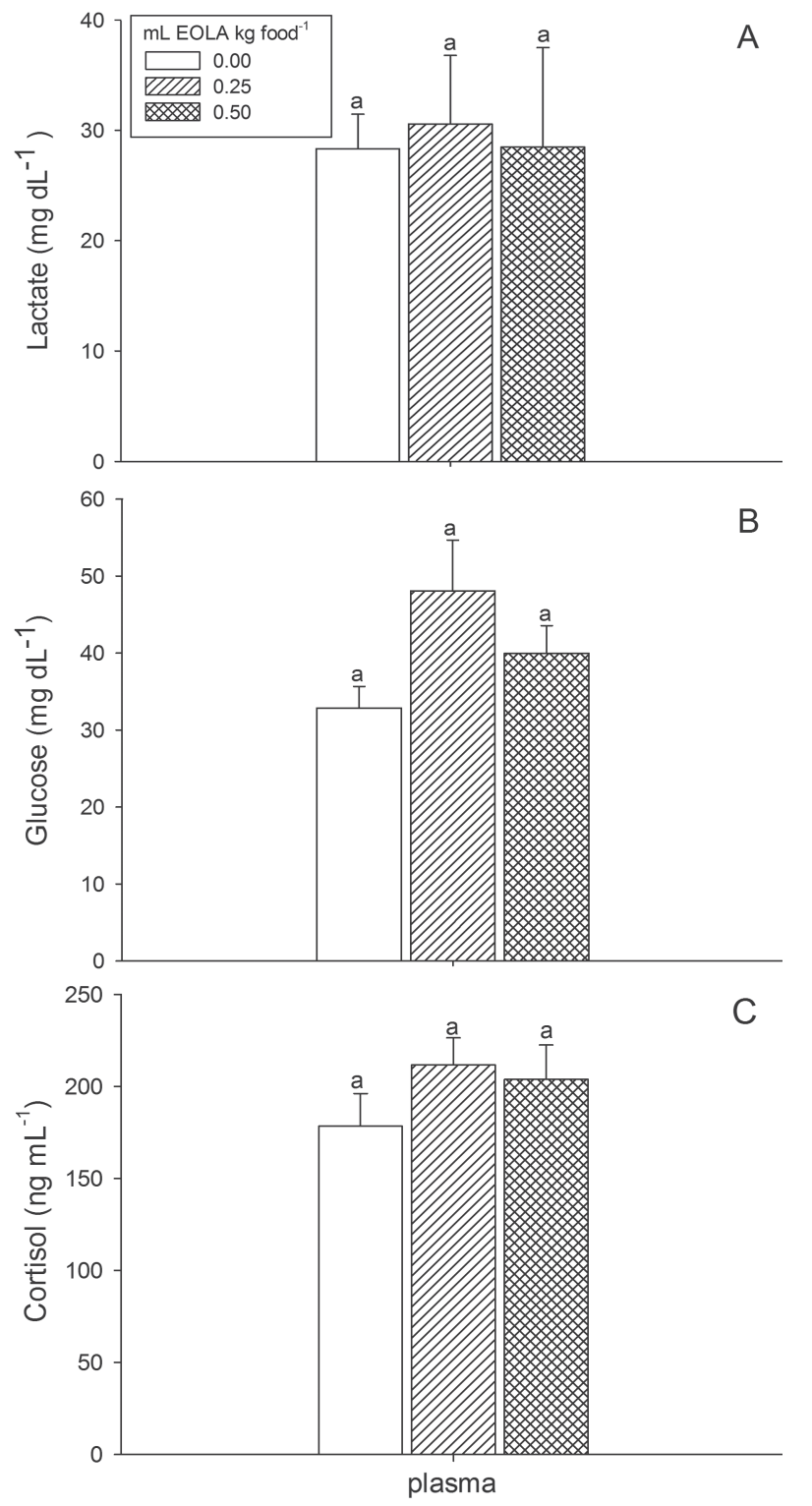

Fig. 1. Plasma lactate (A), glucose (B) and cortisol (C) of Rhamdia quelen fed with different concentrations of dietary essential oil of Lippia alba (EOLA). Mean \pm SEM. Different letters indicate significant differences $(\mathrm{P}<0.05)$ between treatments.
Table 2. Biochemical parameters in liver and muscle of Rhamdia quelen fed with diets containing different concentrations of the essential oil (EO) of Lippia alba. Glycogen $\left(\mu \mathrm{mol} g\right.$ tissue $\left.{ }^{-1}\right)$, glucose $\left(\mathrm{mg} \mathrm{dL}^{-1}\right)$, lactate $\left(\mathrm{mg} \mathrm{dL}^{-1}\right)$, protein $\left(\mathrm{mg} \mathrm{g}^{-1}\right)$, total lipids $(\%$ fat). Values are reported as mean $\pm E S(n=10)$. Significantly different from control group $(\mathrm{P}<0.05)$.

\begin{tabular}{lccc}
\hline & \multicolumn{3}{c}{ Diet $\left(\mathrm{mL} \mathrm{EO} \mathrm{kg} \mathrm{food}{ }^{-1}\right)$} \\
\cline { 2 - 4 } & 0 & 0.25 & 0.50 \\
\hline GIVER & & & \\
Glycogen & $7.24 \pm 0.91$ & $8.44 \pm 1.10$ & $9.57 \pm 1.05$ \\
Glucose & $276.80 \pm 17.54$ & $206.65 \pm 26.50$ & $222.58 \pm 28.66$ \\
Protein & $283.37 \pm 49.89$ & $234.11 \pm 16.65$ & $301.86 \pm 20.80$ \\
Total lipids & $15.79 \pm 4.08$ & $15.25 \pm 0.23$ & $17.61 \pm 2.75$ \\
MUSCLE & & & \\
Glycogen & $1.48 \pm 0.23$ & $1.11 \pm 0.19$ & $1.23 \pm 0.10$ \\
Glucose & $73.62 \pm 12.33$ & $103.04 \pm 6.53$ & $101.33 \pm 5.60$ \\
Lactate & $14.03 \pm 1.21$ & $13.68 \pm 2.34$ & $13.68 \pm 1.24$ \\
Protein & $162.11 \pm 8.73$ & $191.78 \pm 17.39$ & $184.25 \pm 9.53$ \\
Total lipids & $16.74 \pm 1.53$ & $18.98 \pm 5.61$ & $22.90 \pm 3.66$ \\
\hline
\end{tabular}
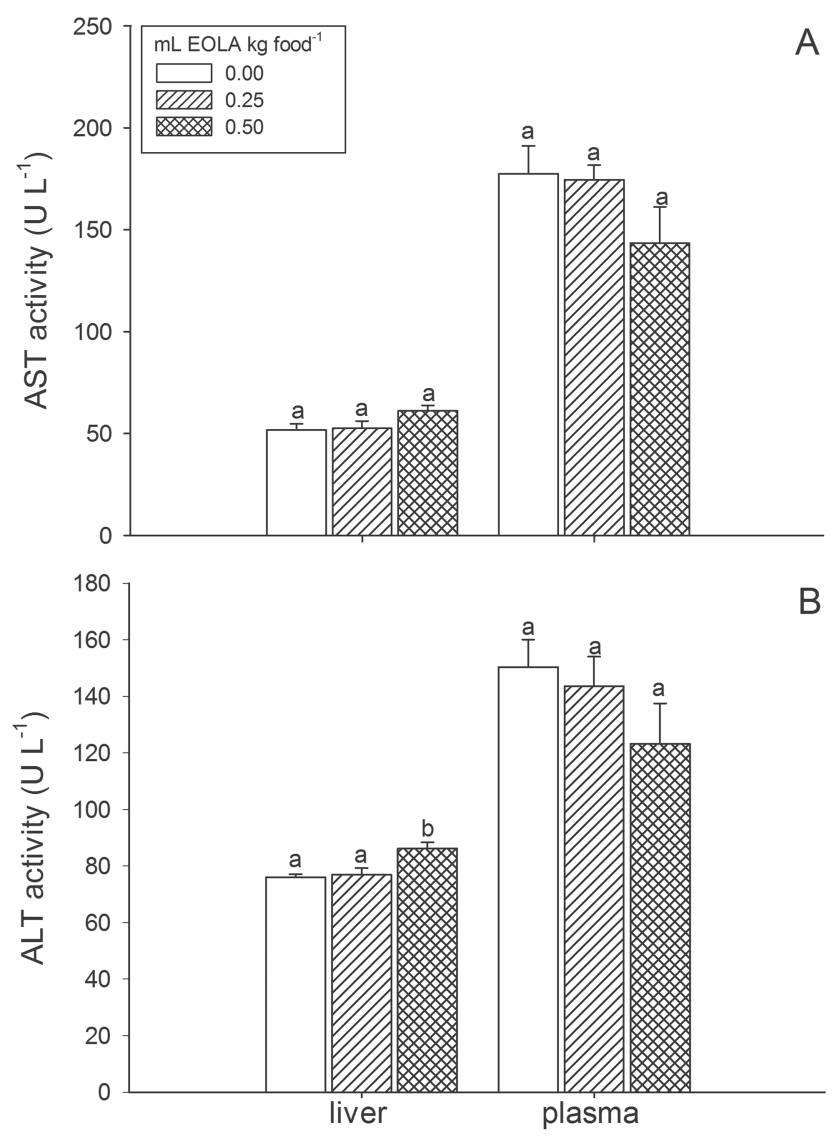

Fig. 2. Plasma and hepatic activities of aspartate aminotransferase (AST) (A) and alanine aminotransferase (ALT) (B) of Rhamdia quelen fed with different concentrations of dietary essential oil of Lippia alba (EOLA). Mean \pm SEM. Different letters indicate significant differences $(\mathrm{P}<0.05)$ between treatments. 
Ions and enzyme activities. Fish fed $0.25 \mathrm{~mL}$ EOLA $\mathrm{kg}$ food ${ }^{-1}$ presented significantly higher $\mathrm{Na}^{+} / \mathrm{K}^{+}$-ATPase activity compared to the other treatments, but plasma $\mathrm{Na}^{+}$, $\mathrm{K}^{+}$and $\mathrm{Cl}^{-}$levels, as well as $\mathrm{H}^{+}$-ATPase activity, were not significantly affected by the treatments (Fig. 3).
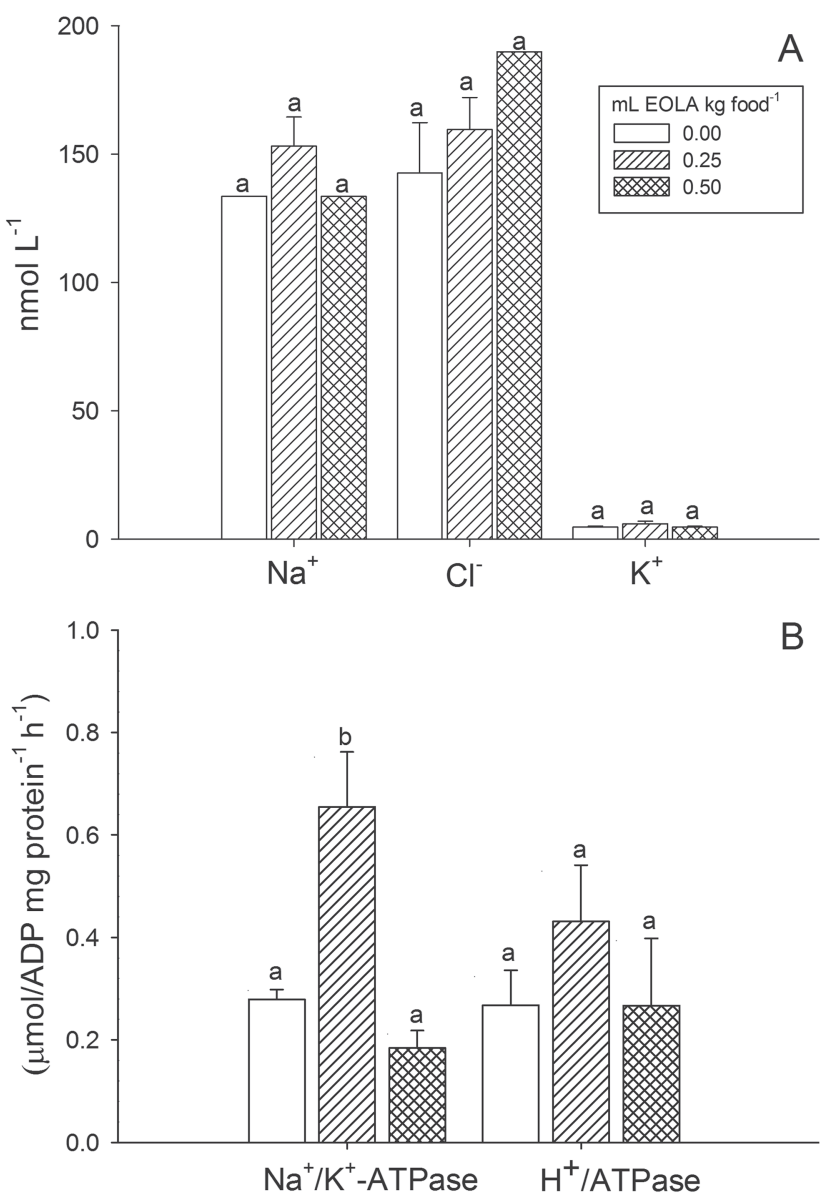

Fig. 3. Osmoregulatory parameters of Rhamdia quelen with different concentrations of dietary essential oil of Lippia alba (EOLA). A) plasma ion levels and B) gill $\mathrm{Na}^{+} / \mathrm{K}^{+}$-ATPase and $\mathrm{H}^{+} /$ATPase activities. Mean \pm SEM. Different letters indicate significant differences $(\mathrm{P}<0.05)$ between treatments.

Hormones expression. Pituitary GH and PRL expressions did not change significantly between groups, but SL expression was higher in the group treated with $0.25 \mathrm{~mL}$ EOLA kg food ${ }^{-1}$ compared to the others (Fig. 4).

\section{Discussion}

High plasma cortisol levels were observed in the control group, demonstrating that the stocking density and the limited space of the $60 \mathrm{~L}$ tanks of the present experiment was stressful for $R$. quelen as previously indicated by Barcellos et al. (2004) and Menezes et al. (2015). According to Barcellos et al. (2001) plasma cortisol values for non-stressed adult $R$. quelen maintained in
$100 \mathrm{~m}^{3}$ ponds with stocking density of $0.8 \mathrm{~kg} \mathrm{~m}^{3}$ are 15 $30 \mathrm{ng} \mathrm{mL}^{-1}$. Immersion anesthesia with EOLA prevented plasma cortisol increase in $R$. quelen subjected to handling (Cunha et al., 2010), but dietary EOLA did not change the levels of such hormone, indicating that it did not have an effect upon stress parameters when administered through this route.

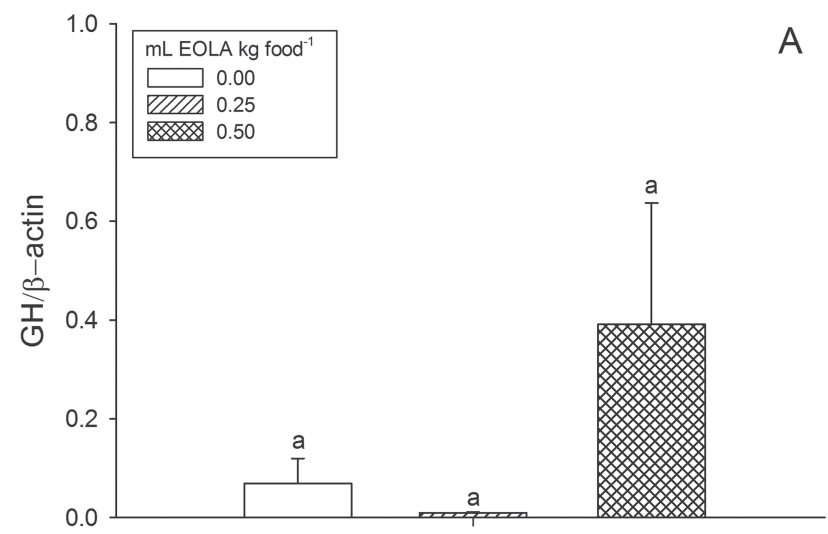
GH Expression (mRNA)
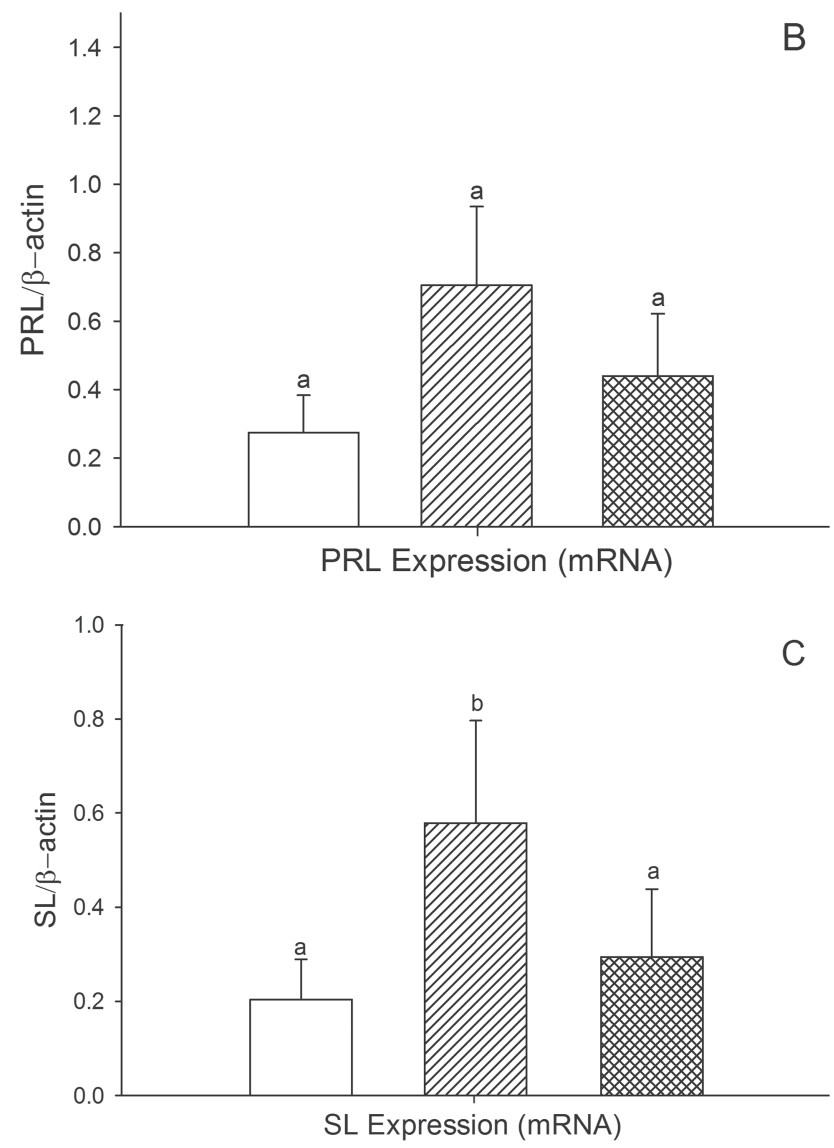

Fig. 4. Expression of pituitary hormones of Rhamdia quelen fed with different concentrations of dietary essential oil of Lippia alba (EOLA). A) growth hormone (GH), B) prolactin (PRL) and C) somatolactin (SL). Mean \pm SEM. Different letters indicate significant differences $(\mathrm{P}<0.05)$ between treatments. 
Lactate, glycogen, glucose, protein and lipids are biochemical parameters commonly used to assess the metabolic state of fish tissues (Pretto et al., 2014). Apparently, dietary addition of both EOLA concentrations for 20 days did not change Rhamdia quelen metabolism since these parameters were not affected. $R$. quelen fed with dietary EOLA for 60 days also did not show significant alteration in most of these biochemical parameters in the plasma, but the liver and muscle glycogen increased and hepatic glucose decreased in $R$. quelen fed $0.50 \mathrm{~mL}^{\text {EOLA kg food }}{ }^{-1}$ (Saccol et al., 2013). Therefore, probably dietary EOLA only change $R$. quelen metabolism after a long-term treatment.

The enzymes AST and ALT are mainly used as biomarkers to assess liver damage, although they are also found in organs such as skeletal muscle, heart, pancreas and kidneys (Gharaei \& Ghaffari, 2010). The increased ALT activity in the liver of silver catfish fed with the highest dietary EOLA concentration suggests that there was hepatocyte damage. However, the lack of alteration in plasma ALT and in plasma and liver AST indicates that the observed increase in hepatic ALT did not cause any serious damage. In agreement with this hypothesis, $R$. quelen fed with up to $2.0 \mathrm{~mL}$ EOLA $\mathrm{kg}$ food ${ }^{-1}$ for 60 days only decreased the glucose levels in the liver, resulting in an increase in the glycogen and lactate reserves in the liver (Saccol et al., 2013).

The addition of EOLA to the water of transport reduced the net $\mathrm{Na}^{+}, \mathrm{K}^{+}$and $\mathrm{Cl}^{-}$losses in $R$. quelen (Becker et al., 2012), and immersion anesthesia with this oil increased gill $\mathrm{Na}^{+} / \mathrm{K}^{+}$-ATPase and $\mathrm{H}^{+} /$ATPase activities in this species (Toni et al., 2014), indicating an osmoregulatory effect. However, the only osmoregulatory effect of dietary EOLA observed in the present experiment was the increase in gill $\mathrm{Na}^{+} / \mathrm{K}^{+}$-ATPase activity in fish fed with $0.25 \mathrm{~mL}$ EOLA $\mathrm{kg}$ food $^{-1}$. The expression of SL also increased in $R$. quelen fed with that concentration of EOLA, indicating that both effects may be related. Previous studies verified a negative relationship between expression of SL and gill $\mathrm{Na}^{+} / \mathrm{K}^{+}$ATPase activity in chum salmon (Oncorhynchus keta) migrating from the ocean to the rivers (Onuma et al., 2010) and in Atlantic salmon (Salmo salar) sampled in the later weeks of smoltification compared to those at the beginning (O'Keeffe et al., 2008). However, both studies compared fish with different reproductive stages, which may have altered expression of SL. The $\mathrm{Na}^{+} / \mathrm{K}^{+}$-ATPase plays a major role in fish osmoregulation (Duarte et al., 2013), while SL seems to be involved with acid-base regulation in rainbow trout (Oncorhynchus mykiss) (Kakizawa et al., 1996) and correction of plasma osmotic balance in Mozambique tilapia (Oreochromis mossambicus) exposed to acidic freshwater (Furukawa et al., 2010). The absence of significant difference in gill $\mathrm{Na}^{+} / \mathrm{K}^{+}$-ATPase activity and SL expression in the fish fed with $0.50 \mathrm{~mL}^{\mathrm{EOLA}} \mathrm{kg}_{\text {food }}{ }^{-1}$ may be because at such concentration the effect was faster and the osmotic and/or acid-base equilibrium was fully reestablished.
Maintenance of GH expression is in accordance with the findings by Saccol et al. (2013), which demonstrated that dietary EOLA did not change $R$. quelen growth. Prolactin is considered one of the most important hormones related to freshwater adaptation, and it is essential for ion uptake as well as reduction in ion and water permeability of osmoregulatory surfaces (Sakamoto \& McCormick, 2006). Its unaltered expression in $R$. quelen fed with dietary EOLA is probably related to the unchanged plasma ion levels.

In conclusion, dietary EOLA does not have a protective effect in $R$. quelen submitted to a stressful situation because it did not alter most measured parameters. The use of $0.25 \mathrm{~mL}$ EOLA $\mathrm{kg}_{\text {food }}{ }^{-1}$ may be more suitable than $0.50 \mathrm{~mL}^{\mathrm{EOLA} \mathrm{kg}}$ food $^{-1}$ since the latter increased ALT, indicating a possible liver damage.

\section{Acknowledgments}

The authors are grateful to the Conselho Nacional de Desenvolvimento Tecnológico (CNPq), Comissão de Aperfeiçoamento de Pessoal de Nível Superior (CAPES), Fundação de Amparo à Pesquisa do Estado do Rio Grande do Sul (FAPERGS-PRONEX) and Ministério da Pesca e Aquicultura/Ministério da Ciência e Tecnologia/ FINEP and INCT-ADAPTA (CNPq - FAPEAM). Authors dedicate this article to professor João Francisco de Oliveira "in memorian".

\section{References}

American Public Health Association (APHA), American Water Works Association \& Water Environment Federation. 2005. Standard methods for the examination of water and wastewater. Edited by Eaton, A. D... [et al.]. Managing editor, Franson, M. A. H. 21st ed. Washington, D. C., American Public Health Association; 2005. 1v. (various pagings).

Azambuja, C. R., J. Mattiazzi, A. P. K. Riffel, I. A. Finamor, L. O. Garcia, C. G. Heldwein, B. M. Heinzmann, B. Baldisserotto, M. A. Pavanato \& S. F. Llesuy. 2011. Effect of the essential oil of Lippia alba on oxidative stress parameters in silver catfish (Rhamdia quelen) subjected to transport. Aquaculture, 319: 156-161.

Baldisserotto, B. 2009. Piscicultura continental no Rio Grande do Sul: situação atual, problemas e perspectivas para o futuro. Ciência Rural, Santa Maria, 39: 291-299.

Baldisserotto, B., J. A. Martos-Sitcha, C. C. Menezes, C. Toni, R. L. Prati, L. O. Garcia, J. Salbego, J. M. Mancera \& G. Martínez-Rodríguez. 2014. The effects of ammonia and water hardness on the hormonal, osmoregulatory and metabolic responses of the freshwater silver catfish Rhamdia quelen. Aquatic Toxicology, 152: 341-352.

Barcellos, L. J. G., L. C. Kreutz, R. M. Quevedo, I. Fioreze, L. Cericato, A. B. Soso, M. Fagundes, J. Conrad, R. K. Baldissera, A. Bruschi \& F. Ritter. 2004. Nursery rearing of jundiá, Rhamdia quelen (Quoy \& Gaimard) in cages: cage type, stocking density and stress response to confinement. Aquaculture, 232: 383-394. 
Barcellos, L. J. G., V. M. Woehl, G. F. Wassermann, R. M. Quevedo, I. Ittzés \& M. H. Krieger. 2001. Plasma levels of cortisol and glucose in response to capture and tank transference in Rhamdia quelen (Quoy \& Gaimard), a South American catfish. Aquaculture Research, 32: 121-123.

Becker, A. G., T. V. Parodi, C. G. Heldwein, C. C. Zeppenfeld, B. M. Heinzmann \& B. Baldisserotto. 2012. Transportation of silver catfish, Rhamdia quelen, in water with eugenol and the essential oil of Lippia alba. Fish Physiology and Biochemistry, 38: 789-796.

Bligh, E. G. \& W. J. Dyer. 1959. A rapid method of total lipid extraction and purification. Canadian Journal of Biochemistry and Physiology, 37: 911-917.

Boyd, C. E. \& C. S. Tucker. 1992. Water quality and pond soil analyses for aquaculture. Auburn: Auburn University, 183p.

Colt, J. 2002. List of spreadsheets prepared as a complement. Available from: http://www.fisheries.org/afs/hatchery htmlS. [accessed: 10th April 2013]. In: Wedemeyer, G. A. (Ed.). 2001, Fish hatchery management, 2nd ed., Bethesda, Md., American Fisheries Society, 733p.

Company, R., A. Astola, C. Pendón, M. M. Valdivia \& J. PérezSánchez. 2001. Somatotropic regulation of fish growth and adiposity: growth hormone $(\mathrm{GH})$ and somatolactin (SL) relationship. Comparative Biochemistry and Physiology, Part C, 130: 435-445.

Council of Europe (COE). 2007. European Pharmacopoeia. 6 th ed. Strassbourg, European Directorate for the Quality of Medicine, 1v.

Cunha, M. A., B. F. Silva, F. A. C. Delunardo, S. C. Benovit, L. C. Gomes, B. M. Heinzmann \& B. Baldisserotto. 2011. Anesthetic induction and recovery of Hippocampus reidi exposed to the essential oil of Lippia alba. Neotropical Ichthyology, 9: 683-688.

Cunha, M. A., F. M. C. Barros, L. O. Garcia, A. P. L. Veeck, B. M. Heinzmann, V. L. Loro, T. Emanuelli \& B. Baldisserotto. 2010. Essential oil of Lippia alba: a new anesthetic for silver catfish, Rhamdia quelen. Aquaculture, 306: 403-406.

Duarte, R. M., M. S. Ferreira, C. M. Wood \& A. L. Val. 2013. Effect of low $\mathrm{pH}$ exposure on $\mathrm{Na}^{+}$regulation in two cichlid fish species of the Amazon. Comparative Biochemistry and Physiology, Part A, 166: 441-448.

Dubois, M., K. A. Gilles, J. K. Hamilton, P. A. Robers \& F. Smith. 1956. Colorimetric method for determination of sugars and related substances. Analytical Chemistry, 28: 350-356.

Furukawa, F., S. Watanabe, T. Kaneko \& K. Uchida. 2010. Changes in gene expression levels of somatolactin in the pituitary and morphology of gill mitochondria-rich cells in Mozambique tilapia after transfer to acidic freshwater $(\mathrm{pH}$ 3.5). General and Comparative Endocrinology, 166: 549555.

Gharaei, A. \& M. Ghaffari. 2010. Correlation between methylmercury accumulation in the kidney and liver and some biochemical parameters of blood sera in juvenile beluga (Huso huso). Veterinary Journal (Pajouhesh \& Sazandegi), 23, no. 3(88): 34-39.

Gibbs, A. \& G. N. Somero. 1989. Pressure adaptation of $\mathrm{Na}^{+} / \mathrm{K}^{+}-$ ATPase in gills of marine teleosts. Journal of Experimental Biology, 143: 475-492.

Harrower, J. R. \& C. H. Brown. 1972. Blood lactic acid-a micromethod adapted to field collection of microliter samples. Journal of Applied Physiology, 32: 709-711.
Ji, S.-C., O. Takaoka, S.-W. Lee, J.-H. Hwang, Y.-S. Kim, K. Ishimaru, M. Seoka, G.-S. Jeong \& K. Takii. 2009. Effect of dietary medicinal herbs on lipid metabolism and stress recovery in red sea bream Pagrus major. Fisheries Science, 75: 665-672.

Kakizawa, S., T. Kaneko \& T. Hirano. 1996. Elevation of plasma somatolactin concentrations during acidosis in rainbow trout (Oncorhynchus mykiss). Journal of Experimental Biology, 199: 1043-1051.

Laiz-Carrión, R., J. Fuentes, B. Redruello, J. M. Guzmán, M. P. Martín del Río, D. Power \& J. M. Mancera. 2009. Expression of pituitary prolactin, growth hormone and somatolactin is modified in response to different stressors (salinity, crowding and food-deprivation) in gilthead sea bream Sparus auratus. General and Comparative Endocrinology, 162: 293-300.

Lazzari, R., J. Radünz Neto, C. A. Veiverberg, G. T. Bergamin, V. Corrêia \& F. A. Pedron. 2007. Alimentação do jundiá (Rhamdia quelen, Heptapteridae) com ingredientes proteicos. Archivos de Zootecnia, 56: 115-123.

Lowry, O. H., N. J. Rosebrough, A. L. Farr \& R. J. Randall. 1951. Protein measurement with the folin phenol reagent. Journal of Biological Chemistry, 193: 265-275.

Menezes, C., I. Ruiz-Jarabo, J. A. Martos-Sitcha, C. Toni, J. Salbego, A. Becker, V. L. Loro, G. Martínez-Rodríguez, J. M. Mancera \& B. Baldisserotto. 2015. The influence of stocking density and food deprivation in silver catfish (Rhamdia quelen): a metabolic and endocrine approach. Aquaculture, 435: 257-264.

Mommsen, T. P., M. M. Vijayan \& T. W. Moon. 1999. Cortisol in teleosts: dynamics, mechanisms of action, and metabolic regulation. Reviews in Fish Biology and Fisheries, 9: 211268.

O'Keeffe, A. M., S. Hubert, M. Voisin, B. Houeix, D. Cotter \& M. T. Cairns. 2008. Somatolactin mRNA expression during the parr-smolt transformation in hatchery-reared Atlantic salmon Salmo salar smolts. Journal of Fish Biology, 73: 436-443.

Onuma, T. A., M. Ban, K. Makino, H. Katsumata, W. W. Hu, H. Ando, M. Fukuwaka, T. Azumaya \& A. Urano. 2010. Changes in gene expression for GH/PRL/SL family hormones in the pituitaries of homing chum salmon during ocean migration through upstream migration. General and Comparative Endocrinology, 166: 537-548.

Perdices, A., E. Bermingham, A. Montilla \& I. Doadrio. 2002. Evolutionary history of the genus Rhamdia (Teleostei: Pimelodidae) in Central America. Molecular Phylogenetics and Evolution, 25: 172-189.

Pfaffl, M. W. 2001. A new mathematical model for relative quantification in real-time RT-PCR. Nucleid Acids Research , 29 (9): e45 (2003-2007). Available from: http://nar.oxfordjournals.org/content/29/9/e45.full. (Nov 2013).

Pretto, A., V. L. Loro, V. M. Morsch, B. S. Moraes, C. Menezes, A. Santi \& C. Toni. 2014. Alterations in carbohydrate and protein metabolism in silver catfish (Rhamdia quelen) exposed to cadmium. Ecotoxicology and Environmental Safety, 100: 188-192.

Reitman, S. \& S. Frankel. 1957. A colorimetric method for the determination of serum glutamic oxaloacetic and glutamic pyruvic transaminases. American Journal of Clinical Pathology, 28: 56-63. 
Saccol, E. M. H., J. Uczay, T. S. Pês, I. A. Finamor, G. M. Ourique, A. P. K. Riffel, D. Schmidt, B. O. Caron, B. M. Heinzmann, S. F. Llesuy, R. Lazzari, B. Baldisserotto \& M. A. Pavanato. 2013. Addition of Lippia alba (Mill) N. E. Brown essential oil to the diet of the silver catfish: an analysis of growth, metabolic and blood parameters and the antioxidant response. Aquaculture, 416-417: 244-254.

Sakamoto, T. \& S. D. McCormick. 2006. Prolactin and growth hormone in fish osmoregulation. General and Comparative Endocrinology, 147: 24-30.

Shalaby, A. M., Y. A. Khattab \& A. M. Abdel Rahman. 2006. Effects of garlic (Allium sativum) and chloramphenicol on growth performance, physiological parameters and survival of Nile tilapia (Oreochromis niloticus). Journal of Venomous Animals and Toxins including Tropical Diseases, 12: 172-201.

Sinha, A. K., M. Diricx, L. P. Chan, H. J. Liew, V. Kumar, R. Blust \& G. De Boeck. 2012. Expression pattern of potential biomarker genes related to growth, ion regulation and stress in response to ammonia exposure, food deprivation and exercise in common carp (Cyprinus carpio). Aquatic Toxicology, 122-123: 93-105.

Terblanché, F. C. \& G. Kornelius. 1996. Essential oil constituents of the genus Lippia (Verbenaceae) - A literature review. Journal of Essential Oil Research, 8: 471-485.
Toni, C., A. G. Becker, L. N. Simões, C. G. Pinheiro, L. L. Silva, B. M. Heinzmann, B. O. Caron \& B. Baldisserotto. 2014. Fish anesthesia: effects of the essential oils of Hesperozygis ringens and Lippia alba on the biochemistry and physiology of silver catfish (Rhamdia quelen). Fish Physiology and Biochemistry, 40: 701-714.

Veeck, A. P. L., B. Klein, L. F. Ferreira, A. G. Becker, C. G. Heldwein, B. M. Heinzmann, B. Baldisserotto \& T. Emanuelli. 2013. Lipid stability during the frozen storage of fillets from silver catfish exposed in vivo to the essential oil of Lippia alba (Mill.) NE Brown. Journal of the Science of Food and Agriculture, 93: 955-960.

Zall, D. M., D. Fisher \& M. Q. Garner. 1956. Photometric determination of chlorides in water. Analytical Chemistry, 28: 1665-1668.

Zheng, Z. L., J. Y.W. Tan, H. Y. Liu, X. H. Zhou, X. Xiang \& K.Y. Wang. 2009. Evaluation of oregano essential oil (Origanum heracleoticum $L$.) on growth, antioxidant effect and resistance against Aeromonas hydrophila in channel catfish (Ictalurus punctatus). Aquaculture, 292: 214-218.

Submitted October 13, 2014

Accepted July 02, 2015 by Adalberto Val Published December 15, 2015 